\title{
Addressing On-board Assaults and Driver Health and Well-Being: A Voluntary Professional Association's Approach
}

\author{
Christopher Lowe ${ }^{a}$, Julia Evans ${ }^{b}$
}

\begin{abstract}
This paper provides an account of how a voluntary professional association (or industry representative body) in Victoria, Australia, led a whole-of-industry response to an alarming increase in on-board assaults on bus drivers by passengers, and the resulting impact on drivers' health and well-being. Influenced by literature and guided by the results from two commissioned research pieces, the association developed and implemented a five pillar strategy to address these issues. A stakeholder perspective was adopted to develop the strategy in order to ensure high relevance and value by being as inclusive as possible across the entire industry, and agency theory underpinned the association's implementation of the strategy. It is hoped that this case study exemplar will assist others in utilising theory for policy change with a view to increase the productivity and social capital of an industry.
\end{abstract}

Keywords

Voluntary professional association, stakeholder perspective, agency theory, health, wellness and safety

In 2013, the Victorian bus and coach industry recognised a significant health and wellbeing concern which was evidenced by a Transport Safety Victoria (TSV) report. This report showed a marked increase in the number of assaults on bus drivers by passengers since 2008. These findings, and related industry concerns, prompted the Bus Association Victoria Inc. (BAV), a voluntary professional association, to create a comprehensive five pillar strategy that endeavoured to address the problem of rising on-board assaults and the flow-on effect to bus driver's health. In developing and implementing the strategy, the BAV adhered to the stakeholder perspective and adopted agency theory as a framework for a co-ordinated, highly consultative and inclusive approach. Preliminary results from this approach indicate that the strategy's implementation has provided the industry with a focus and a process for systematically educating and creating change, not only at an operator level but also at a legislative level through greater evidence-based advocacy for policy reform. The strategy was implemented in 2013, with activity still being undertaken as well as ongoing evaluation and monitoring.

Central to this was the establishment of a Bus Industry Wellness Taskforce. The Taskforce is in charge of enlisting engagement and commitment of BAV members and related industry stakeholders to ensure that initiatives are practical, targeted, and

\footnotetext{
aBus Association Victoria Inc., Australia

bUniversity of Melbourne, Australia

Correspondent Author:

Christopher Lowe, 450 Graham Street, Port Melbourne, Victoria 3207, Australia
} 
relevant to improve workplace practices and support broader industry policy change.

This paper presents the BAV's five pillar strategy to address industry concerns relating to health, safety, and well-being. Section 2 provides some context by describing the current state of the operating environment and the issues associated with the health, well-being, and safety of its workforce. Section 3 presents a literature review on the role of voluntary professional associations - such as the $\mathrm{BAV}$-in developing industry-wide responses to critical issues and the relevance of the stakeholder perspective and agency theory. Section 4 presents the methodology adopted to activate the stakeholder perspective and agency theory and research undertaken that framed the five pillar strategy. Section 5 articulates the five pillar strategy. Section 6 concludes with recommendations for others on how to bridge the nexus between theory and policy outcomes through the adoption of stakeholder perspective and agency theory.

\section{CONTEXT}

Today, it is the law for all Australian employers and workplaces to provide a healthy and safe work environment, free from physical and psychological harm. The terms health, well-being, and safety are specifically used in state and federal legislation, policy and practice. The World Health Organization's definition of "health" has been adopted and refers to an individual's ability to cope with the normal stresses of life, work productively, and make a contribution to the community (World Health Organization 2014). "Well-being" is the level of awareness individuals have when making choices in regards to their own (and others') physical, mental, and social health; and "safety" is about working in a safe way that minimises risk and harm to oneself and others.

In looking at the economic and human cost of health, well-being, and safety in Australia, it has been estimated that one in five Australian adults will be affected by mental illness each year (Australian Bureau of Statistics 2007) with only a third accessing medical services to assist them (Gruen and Lancy 2011). On average, six working days of productivity are lost per year per employee due to stress-related presenteeism and absenteeism, with estimated costs to the Australian economy of AUD $\$ 14.81$ billion per year, and to employers AUD\$10.11 billion a year (Medibank Private and Nous Group 2013). In reporting on the statistics published by Safe Work Australia, Craw (2013) suggested that based on the number of accepted claims for workers compensation for mental stress-related issues, those working in occupations where employees were exposed to potentially dangerous situations have little control over their exposure to traumatic events.

Anecdotal and formal evaluations confirm that bus driving is one of the most hazardous occupations. Bus drivers have been shown to have higher rates of stress, psychological injury, and mental illness, as well as cardiovascular, gastrointestinal, and musculoskeletal health issues than those in other occupations (MacKechnie 2013). Typical examples of assaults on bus drivers by passengers include verbal abuse and swearing, spitting, and hitting the driver, usually after the driver requests the passenger to pay their fare. As a result, there are many implications for drivers, as well as the travelling public are forced to witness such anti-social behaviour. Assaults can result in a range of problems, including anxiety, stress, depression, and post-traumatic stress disorder for both drivers and passengers (Tse, Flin, and Mearns 2006); increased use of alcohol and drugs (Millies 2011); increased workers' compensation claims and personal and property claims from passengers; increased on-road accident rates; work absenteeism, turnover, and poor service quality (Tse, Flin, and Mearns 2004), resulting in reduced patronage as negative incidents discourage bus or public transport use in general. 
The nature and extent of on-board passenger violence and the resulting impact on health, well-being, and safety are relatively unknown in Victoria. A key report issued by TSV in late 2013 and updated in 2016, highlighted significant safety concerns in the Victorian bus and coach industry. They reported a marked increase in the number of assaults on bus drivers by passengers since 2008 (see Table 1).

While legislation in Victoria requires bus drivers and operators to notify TSV of prescribed on-board incidents, abuse, and violence, it has been agreed within the industry that the data are incomplete and that it is likely that bus drivers underreport incidents and injuries. In acknowledgement of this limitation, the Victorian government and the industry are currently in discussions on improved reporting mechanisms for a broader range of on-board incidents.

On-board abuse and driver's health and wellness are of great concern to the Victorian bus and coach industry. The industry is mature and significant, consisting of approximately 600 operators. Two thirds of these operators are contracted to the Victorian government to deliver metropolitan and regional, mainstream and special-school, regional intercity, rail-replacement and airport shuttle bus and coach services. With just over 5,000 buses in Victoria, the industry directly employs approximately 8,000 people, mainly bus drivers, with an additional 3,000 jobs in flow-on effects such as vehicle manufacturers and component suppliers. In 2009, the industry was valued at $\$ 1.1$ billion, or $0.4 \%$ of gross state product (Currie and Delbosc 2009).

The industry is regulated through mandatory legislation and represented by a voluntary professional association, BAV. The Association's membership consisted of 410 operators, with $83 \%$ classified as small operators (1-10 buses), 14\% medium operators (11-100 buses), and 3\% large operators (100+ buses). Most operators are second-, third-, fourth-, and sometimes even fifth-generation operators, a feature common to the industry yet unique given to the youth of enterprise in Australia. These members look to the Association to lead and address industry-wide issues, and realise policy change for improved industry, operator, and community outcomes.

\section{LITERATURE REVIEW}

Three acknowledged fields helped shape the BAV's approach to developing the industry-wide response to on-board assaults and driver's health and safety. Key literature was drawn on with regard to how voluntary professional associations represent member firms and take collective action; the role of stakeholder theory in developing practical plans that satisfy the objectives of individuals and organisations concerned with bus driver's safety and well-being; and how agency theory is critical to effective implementation of improved policy.

\section{Voluntary Professional Associations}

Literature concerning the role of voluntary professional associations and the reasons why firms subscribe and participate as members revealed attempts by some industries to implement industry-wide productivity improvement strategies.

Parada, Nordqvist, and Gimeno (2010) defined voluntary professional associations as organisations created to represent business interests within specific domains, mobilising member firms within these areas so that collective action can be taken to address common problems. Key to any association's success is nurturing and increasing social capital within the association - the development of reciprocity, social networks, and trust between people (Putnam 1995). Through an association's social capital, extensive influence can be placed upon the political agenda, capturing policy initiatives, and reversing institutional developments that generate competition from new entrants. Such social capital holds great value for member firms. 
Table 1. Assaults on Bus Drivers in Victoria 2008-2016 (Personal Communication, June 9, 2016)

\begin{tabular}{lll}
\hline Year & Physical assault of bus driver & Verbal assault of bus driver \\
\hline 2008 & 3 & 3 \\
2009 & 8 & 2 \\
2010 & 6 & 1 \\
2011 & 14 & 2 \\
2012 & 17 & 3 \\
2013 & 16 & 2 \\
2014 & 21 & 5 \\
2015 & 18 & 14 \\
2016 (to May) & 13 & 4 \\
Total & 116 & 36 \\
\hline
\end{tabular}

Bryce (2012) suggested that voluntary professional associations are central to fostering, formulating, performing, and evaluating society's policies that are in the public good. Inherent to this relationship is the association acting as an agent of public policy. As agents, associations leverage their social capital to affect the performance of member firms and their stakeholders in a myriad of interactions. They also facilitate collective action for government by activating the networks, interactions, trust, and reciprocity built among their members. This is what binds the members of the association, fostering a common trust that induces cooperation, and therefore collective action for the public good.

\section{Agency Theory}

Agency theory was found to be equally relevant as it explains the dynamic between the member bus operator firms and the association. The bus operator firm, as the "principal", delegates authority-in terms of control and decision-making about certain tasks - to another party, in this context, the association, as the "agent". When the agent is acting for the principal, it adopts behaviours such as performing for the benefit of the principal or acting as their representative (Fayez, O'Loughlin, and Zutshi 2012: 557). Contributions by scholars such as Ross (1973), Mitnick (1973), Jensen and Meckling (1976), and
Eisenhardt (1989) demonstrate agency theory's relationship within the economic realm. Other scholars have investigated agency theory as it relates to disciplines such as finance, information systems, management, supply chain management (Ritchie, Brindley, and Armstrong 2008), and sociology (Shapiro 1987; 2005).

There are a multitude of tasks that voluntary professional association undertakes as the agent of its members' firms that reflect these relationships and disciplines found in the literature. In the context of the bus and coach industry in Australia, the BAV - as a voluntary professional association-leads the negotiation of bus service contracts with the state government, industrial relations agreements with the union, and resolves operating issues that have the potential to affect all bus operator firms and the industry more broadly, particularly on matters that concern driver's and passenger's safety, technical requirements, contract disputes, and legislative and regulatory interpretations (Bus Association Victoria Inc. 2015).

To an extent, voluntary professional association also acts as an agent of the state government. The state government looks to the association to achieve public policy outcomes. So both the operator and the state government, as principals, seek the services of the association as their agent. 
Lowe (2016) has been the first to raise the concept of an agent representing and negotiating with two principals (member operators and government), making the agency circumstances of this study unique. The unique structural relationships among operators, a voluntary professional association, and the government are illustrated in Figure 1.

\section{The Stakeholder Perspective}

Positioned within stakeholder theory, the stakeholder perspective offers insights into a voluntary professional association's propensity to undertake some level of industry performance on behalf of its members to achieve social legitimacy for the public good. Freeman's (1984) landmark publication identified the groups that are stakeholders of a corporation, describing and recommending methods by which management can give due with regard to the interests of those groups. Stakeholder theory questions the established view that the firm's first responsibilities are to its shareholders. Stakeholder theory argues that other parties are involved, including government bodies, political groups, trade associations, trade unions, communities, financiers, suppliers, employees, and customers in bringing about a return to a firm's shareholders. A premise of the stakeholder perspective is that focusing attention on all stakeholders will lead to increased trust and cooperation and reduced opportunism.

The stakeholder perspective has been presented as an instrumental theory for evaluating corporate social performance (Carroll 1991; Clarkson 1995), social contracting (Donaldson and Dunfee 1994), the purpose of a firm (Brenner and Cochran 1991; Donaldson and Preston 1995), family firms (Neubaum, Dibrell, and Craig 2012), and the challenges that globalisation brings to stakeholder theory (Jensen and Sandström 2011). The stakeholder perspective is notable as one of the main frameworks for corporate social responsibility. In fields such as law, management, and human resources, stakeholder theory succeeds in challenging the usual analytic frameworks by suggesting firms put stakeholders' needs at the centre of any action or organisation.

In developing a whole-of-industry strategy, the BAV adopted the stakeholder perspective. This provided a framework that endeavoured to be as inclusive as possible with individuals, operators, organisations, government, and the community in developing a plan that addressed their concerns. It was envisaged by the BAV that such an approach would sharpen recommendations for the association to pursue and increase the speed at which operators (in the main) would implement new practices. In developing the strategy, the BAV acted in a manner consistent with agency theory, leading the development on behalf of its membership.

\section{METHODOLOGY}

With the stakeholder perspective and agency theory in mind, the BAV established a Taskforce and commissioned research to help guide the formulation of a strategic response to on-board assaults and driver's health and safety.

\section{The Bus Industry Wellness Taskforce}

Key to the strategy was the establishment of the Bus Industry Wellness Taskforce to enlist the commitment of the association's members and facilitate greater engagement with those connected with the industry with an interest in ensuring the industry's health and productivity. The role of the Taskforce is to work with the association throughout the development and implementation of the five pillar strategy to ensure that initiatives are relevant and practical in addressing industry's health and wellness.

The Taskforce consists of bus operators from the association's membership (representing a range of metropolitan and regional contexts), executives from the association, and three external practitioners with mental health, sociology, and workplace education 


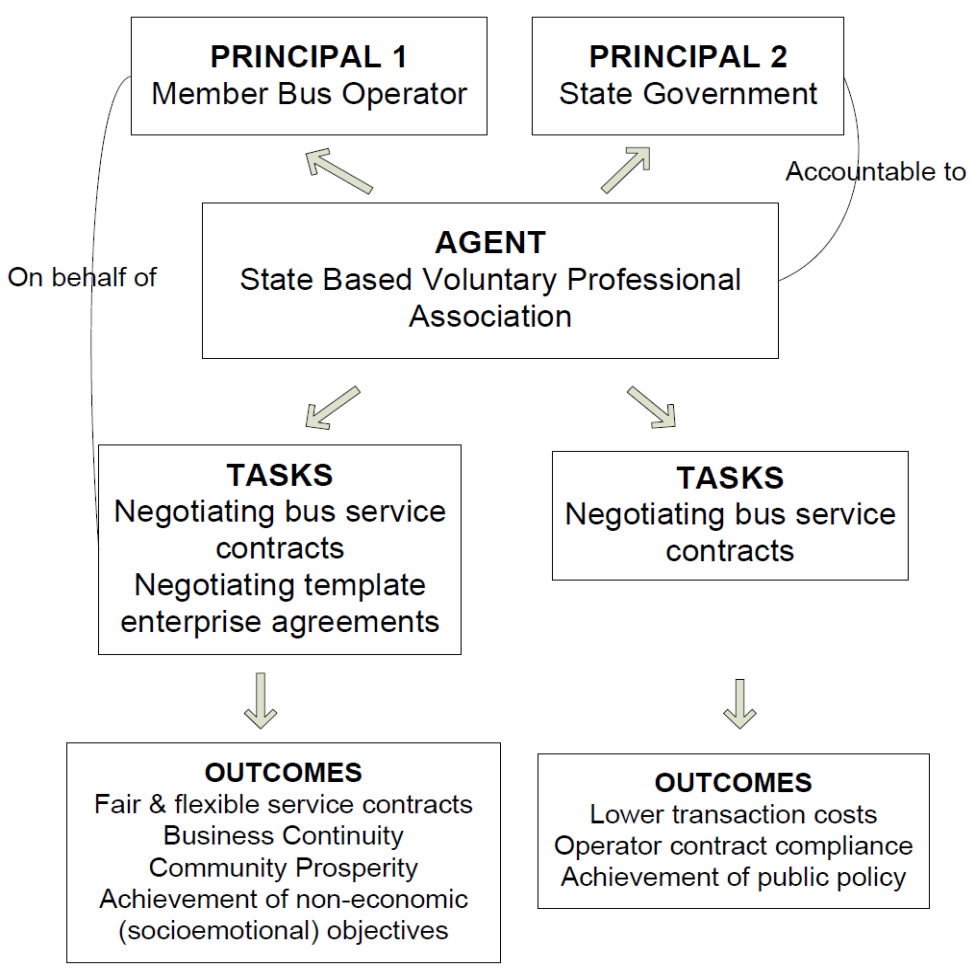

Figure 1. Agency Theory in the Context of the Australian Bus and Coach Industry (Lowe 2016).

expertise. Meeting regularly and overseen by an independent Chair, the Taskforce sought deep consultation with state government agencies, regulators, and the union, and established broader engagement from similar industries, such as trucking transport, taxi, and emergency services.

\section{Commissioned Research}

In commencing development of a strategic response, the Taskforce recognised the need to quantify the number and nature of non-reported on-board passenger assaults, the factors that may contribute to such incidents, the effect these might have on industry personnel, and how similar industries have approached developing and implementing industry-wide strategies for improving health, well-being, and safety. As a result, two studies were commissioned in 2014.

The first, "Review of the Mental Health and Well-Being of the Bus and Coach Industry" (mh@work ${ }^{\circledR} 2015$ ) included a 32-question online and paper-based survey that was sent to 8,000 industry personnel in Victoria. The survey asked questions around the challenges experienced at home and work, the impact of these on physical and mental health, passenger aggression, and bus driver experiences. The survey received a $13 \%$ return rate, with $81 \%$ completed by bus drivers. To support the dissemination of the online survey, a researcher was on-site to promote the survey at 13 metropolitan and regional depots over 25 days. Additionally, an external statistician was engaged to assist with the quantification and analysis. The survey provided for qualitative and quantitative data on the scope and scale of on-board incidents and their impact on drivers' health, well-being, and safety, in order to inform policy and programmes moving forward. Consistent with stakeholder perspective, the primary stakeholders being the two government regulators, the union and 
the association, agreed to co-contribute to funding this industry-wide survey.

The second research piece undertaken was "Report on the Prevention of Aggression to Bus Drivers in Victoria" (Stanley 2015). This report explores the reasons for violence towards bus drivers, what prevention methods are suggested from these findings, and knowledge gained elsewhere that may lead to a reduction of the occurrence of aggression and the severity of the event. The report also detailed the theory about aggression: its causes, components, and impacts. Together with the association, the Taskforce drew on the key findings from these research studies to shape the five pillar strategy.

\section{DISCUSSIONS}

\section{The Five Pillar Strategy}

The whole-of-industry response to reducing on-board assaults and improving driver's health, safety, and wellness has been guided by the creation and implementation of a five pillar strategy. Commencing in 2013, the first three pillars have been completed and currently in play are the last two.

The first pillar of the strategy was "research". As commissioned by the association and Taskforce, the mh@work ${ }^{\circledR}$ (2015) report produced critical data associated with the frequency and nature of passenger aggression towards bus drivers and how drivers respond and report incidents to their employers. This study found that $25 \%$ of bus drivers experience abuse at least once a week. When asked what caused this behaviour, drivers cited passengers affected by drugs and/or alcohol and reacting to requests to validate or purchase a ticket. The report also identified the impact of these incidents on driver's health and wellness. Impacts include increased sick leave, demotivation, changing sleep patterns, eating disorders, stress, anxiety, depression, headaches, stomach aches, and feelings of hopelessness, worthlessness, and helplessness. The report featured recommendations that survey respondents believe would improve the quality of their work environment, such as improved employer/employee consultation, increased government inspector deployment, public education campaigns, bus staff education on fitness, nutrition, lifestyle, and assertiveness training.

The Stanley (2015) report makes recommendations to prevent aggression to bus drivers. These include increasing the effort and risks that need to be made by a potential perpetrator to lessen the propensity of a potential assault, and reducing the rewards to offenders of no or soft penalties for offenses. These two research pieces informed the direction of the remaining pillars.

The second pillar of the strategy was "education", and included three initiatives. First, the Taskforce and government stakeholders (Public Transport Victoria and Transport Safety Victoria) agreed upon the need for the creation of a state-wide campaign to curb anti-social behaviour on buses (and public transport more generally). Second, the need for the development of a bespoke suite of resource guides for the industry was recognised. After considering the industry and its operators, three guides were developed - an operators' guide on making health, well-being, and safety, a strategic priority in their firms; a guide for managers and supervisors on making health, well-being, and safety, a daily priority; and finally, a general guide providing practical ideas and resources to improve health and fitness, bus driver's safety, general skills, and support, and creating a greater sense of belonging and increasing workplace responsibility. These resource guides were launched in October 2015 and are freely available to members and the general public. Thirdly, the association and government stakeholders agreed to co-contribute to the funding of an educational resource to educate secondary school students in metropolitan and regional centre schools about passenger etiquette, the dangers of rock-throwing and 
other forms of anti-social behaviour, and the importance of fare compliance.

The third pillar of the strategy was "financial". The association is leading the design, trial, and installation of driver security screens in buses to act as both a safety feature for drivers and a deterrent from potential on-board assaults. Additionally, the Taskforce was able to obtain agreement from key agencies, regulators, and the union to co-operatively fund the measures within this pillar, as they had a plural benefit and could not be undertaken in kind.

The fourth pillar of the strategy was "legislative". This pillar seeks ongoing lobbying and advocacy with the state government to amend legislation to include bus drivers as emergency workers (akin to police, ambulance, fire brigade, and State Emergency Service officers), so longer sentences ensue for those who are prosecuted for assaulting bus, public transport, or emergency workers (although the Victorian Attorney General denied the request in 2015, a similar legislative change was supported in Ontario, Canada in 2015); and amend legislation, so Public Safety Officers can work on the state's bus and coach network rather than just the metropolitan rail network.

The fifth pillar of the strategy was "enforcement", requiring advocacy with the state government to deploy more Authorised Officers and transit police patrols on the bus network to promote passenger safety and curb anti-social or illegal consumer behaviour.

\section{Impact to Date}

Since the launch of the "research" and "education" pillars from 2013 to 2015 , primary outcomes include:

(1) Improved bus driver's morale, sense of safety, and job satisfaction. An industry-wide survey will occur late 2016 to compare results to the mh@work ${ }^{\circledR}$ (2015) study on health and wellness;

(2) Improved productivity of the industry, measured by total service kilometres delivered and number of lost hours.
Secondary outcomes have been deeper level of partnership with the safety regulator and other state agencies with the industry to focus on these issues; enquiries from other employer groups and industry associations seeking consultations on the five pillar approach as a model to use when responding to industry-wide or social issues; and academic interest, with the submission of papers for publication to two international conferences.

\section{CONCLUSIONS}

The health, well-being, and safety of all personnel are a concern for all industries that is often articulated into Australian legislation. Voluntary professional associations can play an important and effective role in assisting member firms in meeting their legal obligations in this regard by using, and improving upon, the social capital of the industry. In the case of aggression towards bus drivers and the health issues that stem from these incidents, the BAV led the creation of a five pillar strategy that addresses these concerns. It was found that the creation of the Taskforce became an effective vehicle for managing the stakeholder perspective, and ensuring that the final strategy satisfies stakeholders' concerns. The association's activation of the strategy aligned with agency theory, acting for, and on behalf of a community of interest for better collective industry-wide outcomes. The Taskforce is a rich and necessary resource throughout the development and implementation of the five pillar strategy, as initiatives were heavily influenced by a nuanced generational understanding of the industry, and implementation greatly accelerated by long-standing relationships within the industry. It is hoped that this approach to addressing critical industry issues might be of value by other voluntary professional associations looking to address industry-wide social concerns affecting the well-being of their personnel and the productivity of their industry. 


\section{References}

Australian Bureau of Statistics. 2007. National Survey of Mental Health and Well-Being. Retrieved July 17, 2016 (ht tp://www.abs.gov.au/AUSSTATS/abs@.nsf/Latestproducts/ 4326.0Main\%20Features32007?opendocument\&tabname= Summary \&prodno $=4326.0 \&$ issue $=2007 \&$ num $=\&$ view $=$ ).

Brenner, S. N. and P. L. Cochran. 1991. "The Stakeholder Model of the Firm: Implications for Business and Society Research." Pp. 449-467 in Proceedings of the Second Annual Meeting of the International Association for Business and Society, edited by J. F. Mahon. Sundance, UT.

Bryce, H. 2012. Players in the Public Policy Process: Non-profits as Social Capital and Agents. USA: Palgrave Macmillan.

Bus Association Victoria Inc. 2015. Welcome. Retrieved July 17, 2016 (http://www.busvic.asn.au/public/).

Carroll, A. B. 1991. "The Pyramid of Corporate Social Responsibility: Toward the Moral Management of Organizational Stakeholders." Business Horizons 34(4):39-48.

Clarkson, M. B. E. 1995. "A Stakeholder Framework for Analyzing and Evaluating Corporate Social Performance." Academy of Management Review 20:92-117.

Craw, V. 2013. Train Drivers Have the Toughest Job in the Country. Retrieved (http://www.news.com.au).

Currie, G. and A. Delbosc. 2009. 2009 Victorian Bus Industry Survey. Institute of Transport Studies, Department of Civil Engineering, Monash University. Retrieved July 17, 2016 (http://www.busvic.asn.au/images/uploads/public/Vic_Bus_ Industry_Survey_2009_-_Monash.pdf).

Donaldson, T. and L. E. Preston. 1995. "The Stakeholder Theory of the Corporation: Concepts, Evidence, and Implications." Academy of Management Review 20:65-91.

Donaldson, T. and T. Dunfee. 1994. "Toward a Unified Conception of Business Ethics: Integrative Social Contracts Theory." Academy of Management Review 19(2):252-284.

Eisenhardt, K. M. 1989. "Agency Theory: An Assessment and Review." Academy of Management Review 14(3):488-511.

Fayez, S., A. O'Loughlin, and A. Zutshi. 2012. "Agency Theory and Supply Chain Management: A Structured Literature Review." Supply Chain Management: An International Journal 75(5):556-570.

Freeman, R. E. 1984. Strategic Management: A Stakeholder Approach. Boston, MA: Pitman.

Gruen, N. and A. Lancy. 2011. Lateral Economics Index of Australia's Well-Being. Retrieved July 17, 2016 (http:// lateraleconomics.com.au/wp-content/uploads/2014/02/Fairf ax-Lateral-Economics-Index-of-Australias-Well-being-Fina 1-Report.pdf).

Jensen, M. C. and W. H. Meckling. 1976. "Theory of the Firm:
Managerial Behaviour, Agency Costs and Ownership Structure." Journal of Financial Economics 3(4):305-360.

Jensen, T. and J. Sandström. 2011. "Stakeholder Theory and Globalization: The Challenges of Power and Responsibility." Organization Studies 32(4):473-488.

Lowe, C. 2016. The Social Externalities of Australian Bus and Coach Operators: How Governance Affects Community Prosperity. Retrieved July 17, 2016 (http://search.lib. monash.edu/primo_library/libweb/action/dlSearch.do?vid= MON\&mode $=$ Basic\&institution $=$ MUA\&search_scope $=$ au everything\&tab $=$ default_tab\&query $=$ any $\% 20$ contains $\% 20$ s ocial\%20externalities\%20bus\%20and\%20coach).

MacKechnie, C. 2013. Bus Driver Health. Retrieved July 17, 2016 (http://www.publictransport.about.com/od/Transit_ Employment/a/Bus-DriverHealth.htm).

Medibank Private and Nous Group. 2013. The Case for Mental Health Reform in Australia: A Review of Expenditure and System Design. Retrieved July 17, 2016 (http://www. medibank.com.au/Client/Documents/Pdfs/The_Case_for_M ental_Health_Reform_in_Australia.pdf).

mh@work ${ }^{\circledR}$. 2015. Review of the Mental Health and Well-Being of the Bus and Coach Industry. Retrieved July 17, 2016 (http://www.busvic.asn.au/images/uploads/links/ A_Review_of_Mental_Health_and_Well_Being_of_the_B us_and_Coach_Industry___January_2015.pdf).

Millies, B. A. 2011. "Truck and Bus Driving." In Encyclopedia of Occupational Health and Safety, edited by Road Transport and L. Byrd. Geneva: International Labor Organisation.

Mitnick, B. 1973. "Fiduciary Rationality and Public Policy: The Theory of Agency and Some Consequences." Presented at the Annual Meeting of the American Political Science Association, n.d., New Orleans, LA.

Neubaum D. O., C. C. Dibrell, and J. B. Craig. 2012. "Balancing Natural Environmental Concerns of Internal and External Stakeholders in Family and Non-family Businesses." Journal of Family Business Strategy 3:28-37.

Parada, M., M. Nordqvist, and A. Gimeno. 2010. "Institutionalising the Family Business: The Role of Professional Associations in Fostering a Change of Values." Family Business Review 23(4):355-372.

Putnam, R. 1995. "Bowling Alone: America's Declining Social Capital." Journal of Democracy 6(1):5-8.

Ritchie, B., C. S. Brindley, and N. Armstrong. 2008. "Risk Assessment and Relationship Management: Practical Approach to Supply Chain Risk Management." International Journal of Agile Systems and Management 3(3-4):228-247.

Ross, S. A. 1973. "The Economic Theory of Agency: The Principal's Problem." American Economic Review 63(2):134-139. 
Shapiro, S. P. 1987. "The Social Control of Impersonal Trust." American Journal of Sociology 93(3):623-658.

2005. "Agency Theory." Annual Review of Sociology 31:263-284.

Stanley, J. 2015. Prevention of Aggression to Bus Drivers. Retrieved July 17, 2016 (http://www.busvic.asn.au/images/ uploads/links/Prevention_of_Aggression_to_Bus_Drivers.p df).

Tse, J. L. M., R. Flin, and K. Mearns. 2004. "Bus-Ting a Gut-The Strains of an Urban Bus Driver." Presented at the 3rd International Conference of Traffic \& Transport Psychology (ICTTP), Nottingham, England.

—. 2006. "Bus Driver Well-Being Review: 50 Years of Research." Transportation Research Part F 9:89-114.

World Health Organization. 2014. Mental Health: A State of Well-Being. Retrieved July 17, 2016 (http://www.who.int/ features/factfiles/mental_health/en).

\section{Bios}

Christopher Lowe, MBA, Ph.D., executive director at Bus Association Victoria Inc., Melbourne, Victoria, Australia; research fields: public transport operator governance, family businesses, quantification of externalities, community and regional development, association management.

Julia Evans, BA, BedT, MEd, DEd, project manager with the Australian Academy of the Humanities and a senior research fellow at the University of Melbourne's Melbourne Graduate School of Education; research field: research and advocacy that promotes the humanities in national policy development. 